\title{
Socio-Political And Economic Determinants Of Income Inequality In Indonesia
}

\author{
Ichsan Zulkarnaen' \\ Ministry of National Development Planning/BAPPENAS
}

\begin{abstract}
Income inequality in Indonesia has rapidly enlarged in recent years. This paper aims to examine the causes of highly persistent income inequality in Indonesia. In contrast to other previous studies that investigated income inequality focusing only on economic factors, this paper also looks at social and political elements. Using Ordinary Least Square (OLS) method, I found that democracy has no significant impact on income inequality. In addition, the study found a significant relationship between government spending and income inequality. In addition, I also found evidence that foreign direct investment (FDI) flows have an impact to improve income inequality in Indonesia. There are several relevant policy conclusions that can be drawn from this study.
\end{abstract}

Keywords: Income inequality, Indonesia, OLS, FDI, Democracy. Government Spending 


\section{Socio-Political And Economic Determinants Of Income Inequality In Indonesia}

\section{Background}

After the collapse of the New Order era in 1998, Indonesia entered the Reform era which was marked by the implementation of the most democratic general elections in Indonesia. The process of democratization in Indonesia continued until 2004 when, for the first time, the people of Indonesia could directly choose their President and Vice President as well as the members of parliament.

Unfortunately, the improvement in the democratization process is not followed by improvement in income inequality. The issue of income inequality has attracted the attention of policy makers, especially in Indonesia (Anshori et al, 2013). Based on the data from the Central Agency of Statistics, the average National Gini Index during the democratic era (2004 - to date) reaches 0.39. Even worse, since 2012 until 2015, the Gini Index reached 0.41 or the highest level so far. Meanwhile, during the New Order era under Soeharto, the average level of the Gini Index in Indonesia reached 0.32 .

Figure 1. Income inequality in Indonesia

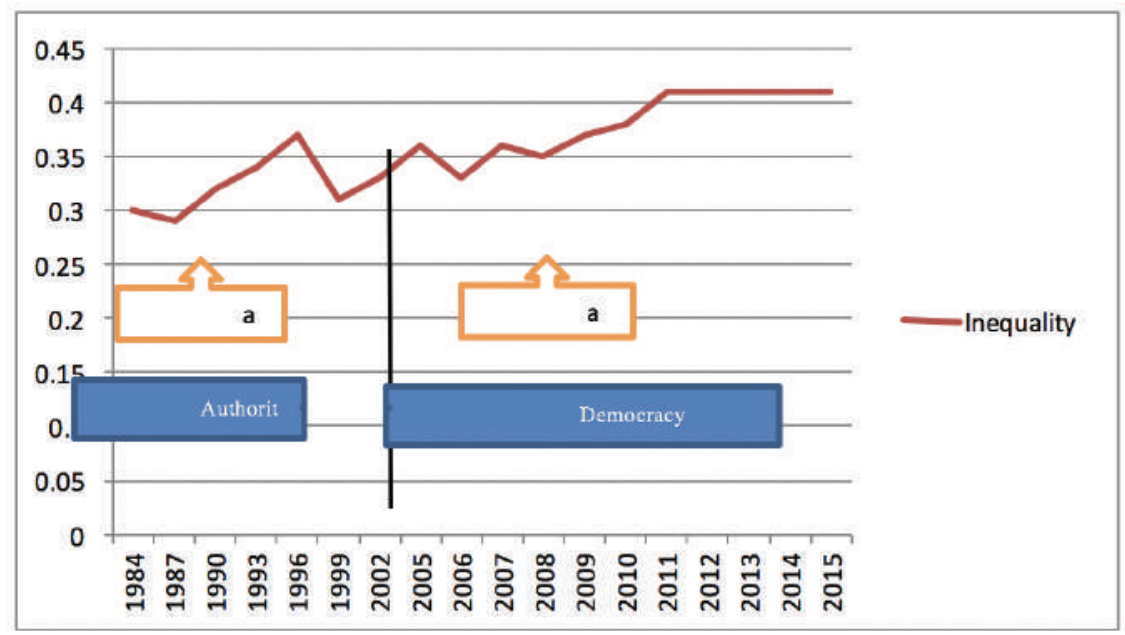

Source: World Development Indicator, The World Bank

Many scholars argue that democracy can enhance community participation, which in turn allows a greater number of people to demand more equitable redistribution of income (Boix, 1998) while governments under the authoritarian regime tend to implement policies that benefit middle and upper income society and it will increase income inequality (Reuveny and Li, 2003).

Based on the description above, the relevant question is why democracy in Indonesia has not been able to reduce the level of income inequality despite the level of democracy in Indonesia is improving?

2 According to the data from Freedom House, the index of political rights in Indonesia has decreased means it moves toward more democracy. 
In this paper I will analyze the impact of economic and socio-political factors on income inequality in Indonesia. In this paper, I will use 33 provincial economic and socio-political data including: Gini index for each province, the ratio of regional government spending on education, health, and salary; the level of regional GDP per capita, mean years of schooling, and foreign direct investment. I also include provincial democracy index as my primary interest and utilize a cross sectional analysis to estimate the impact of those social, economic and political data on income inequality in Indonesia.

This paper is organized as follows. In the next section I will present the regional data then, I will describe some theoretical perspectives followed by literature review. Finally, I present my methodology, the results of the analysis and the conclusion.

\subsection{Income Inequality in Indonesia : Trends}

In this part, I will describe the trend of income inequality in Indonesia from the authoritarian regime until the democratic government.

There was a moderate Gini index before 1998/1999 when the democracy was introduced. The average Gini coefficient from 1990-1999 stood at 0.32 per year. However, after democracy was introduced, the average had risen to 0.39 per year. For more than a decade, the Gini index had fluctuated between 0.33 to 0.41 .

What about trends in inter-provincial inequality? Table 1 below presents the provincial Gini Index in Indonesia. Again, there was a relatively low average of Gini Index in Indonesia before 2004.

Table 1. Provincial Income Inequality (1996 - 2015)

\begin{tabular}{|c|c|c|c|c|c|c|}
\hline Island/Province & 1996 & 2005 & 2009 & 2012 & 2015 & 2015 vs 2005 \\
\hline \multicolumn{7}{|l|}{ Sumatera Island } \\
\hline Nanggroe Aceh Darussalam (NAD) & 0.26 & 0.30 & 0.29 & 0.32 & 0.33 & +0.03 \\
\hline North Sumatera & 0.30 & 0.33 & 0.32 & 0.33 & 0.34 & +0.01 \\
\hline West Sumatera & 0.28 & 0.30 & 0.30 & 0.36 & 0.34 & +0.04 \\
\hline Riau & 0.30 & 0.28 & 0.33 & 0.40 & 0.36 & +0.08 \\
\hline Jambi & 0.25 & 0.31 & 0.27 & 0.34 & 0.36 & +0.05 \\
\hline South Sumatera & 0.30 & 0.31 & 0.31 & 0.40 & 0.36 & +0.05 \\
\hline Bengkulu & 0.27 & 0.35 & 0.30 & 0.35 & 0.38 & +0.03 \\
\hline Lampung & 0.28 & 0.38 & 0.35 & 0.36 & 0.38 & +0.00 \\
\hline Bangka Belitung & - & 0.28 & 0.29 & 0.29 & 0.28 & +0.00 \\
\hline Riau Island & $\cdot$ & 0.27 & 0.29 & 0.35 & 0.36 & +0.09 \\
\hline \multicolumn{7}{|l|}{ Java-Bali Island } \\
\hline DKI Jakarta & 0.36 & 0.27 & 0.36 & 0.42 & 0.43 & +0.06 \\
\hline West Java & 0.36 & 0.34 & 0.36 & 0.41 & 0.41 & +0.07 \\
\hline Central Java & 0.29 & 0.31 & 0.32 & 0.38 & 0.38 & +0.07 \\
\hline Di Yogyakarta & 0.35 & 0.42 & 0.38 & 0.42 & 0.43 & +0.01 \\
\hline East Java & 0.31 & 0.36 & 0.33 & 0.36 & 0.42 & +0.06 \\
\hline Banten & - & 0.36 & 0.37 & 0.39 & 0.40 & +0.04 \\
\hline Ball & 0.31 & 0.33 & 0.31 & 0.42 & 0.38 & +0.05 \\
\hline West Nusa Tenggara & 0.29 & 0.32 & 0.35 & 0.35 & 0.37 & +0.05 \\
\hline East Nusa Tenggara & 0.30 & 0.35 & 0.36 & 0.36 & 0.34 & -0.01 \\
\hline \multicolumn{7}{|l|}{ Kalimantan Island } \\
\hline West Kalimantan & 0.30 & 0.31 & 0.32 & 0.38 & 0.33 & +0.02 \\
\hline Central Kalimantan & 0.27 & 0.28 & 0.29 & 0.38 & 0.33 & +0.05 \\
\hline South Kalimantan & 0.29 & 0.32 & 0.35 & 0.38 & 0.35 & +0.03 \\
\hline
\end{tabular}




\begin{tabular}{|l|c|c|c|c|c|c} 
East Kalimantan & 0.32 & 0.32 & 0.38 & 0.36 & 0.32 & +0.00 \\
\hline Sulawesi Island & & & & & \\
\hline North Sulawesi & 0.34 & 0.32 & 0.31 & 0.43 & 0.37 & +0.05 \\
\hline Central Sulawesi & 0.30 & 0.30 & 0.34 & 0.40 & 0.37 & +0.07 \\
\hline South Sulawesi & 0.32 & 0.35 & 0.39 & 0.41 & 0.42 & +0.07 \\
\hline Southeast Sulawesi & 0.31 & 0.36 & 0.36 & 0.40 & 0.40 & +0.04 \\
\hline Gorontalo & - & 0.36 & 0.35 & 0.44 & 0.42 & +0.06 \\
\hline West Sulawesi & - & - & 0.30 & 0.31 & 0.36 & +0.06 \\
\hline Maluku-Papua Island & & & & & & +0.38 \\
\hline Maluku & 0.27 & 0.26 & 0.31 & 0.34 & +0.38 \\
\hline North Maluku & - & 0.26 & 0.33 & 0.34 & 0.28 & +0.02 \\
\hline West Papua & - & - & 0.35 & 0.43 & 0.44 & +0.09 \\
\hline Papua & 0.39 & 0.39 & 0.40 & 0.44 & 0.42 & +0.03 \\
\hline Indonesia & 0.36 & 0.36 & 0.37 & $\mathbf{0 . 4 1}$ & $\mathbf{0 . 4 1}$ & +0.05 \\
\hline
\end{tabular}

Source: Statistics of Indonesia, various editions

Figure 2 provides different picture. It shows variations in regional GDP per capita across provinces in Indonesia in 2010. Clearly, per capita regional GDP in DKI Jakarta and East Kalimantan are far above the average.

Figure 2. RGDP per Capita (in real term2010) (in Thousand)

o 50000000100000000150000000

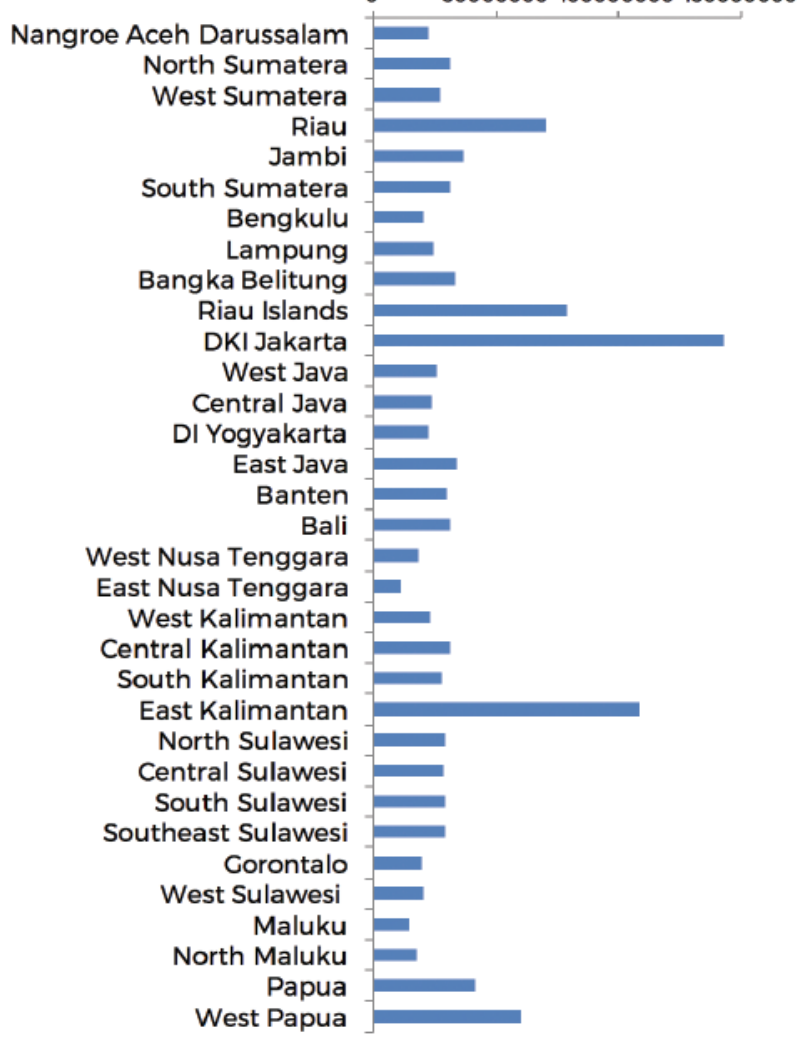


Interestingly, DKI Jakarta is among provinces with the highest level of democracy and the highest GDP per capita. Unfortunately, DKI Jakarta also has higher Gini Indexes compared to the average Gini Index in 2015.

Table 2. Democracy Index (2015)

\begin{tabular}{|c|c|c|}
\hline & Province & Democracy Index \\
\hline \multirow{5}{*}{ The Highest } & DKI Jakarta & 85.32 \\
\hline & DI Yogyakarta & 83.19 \\
\hline & East Kalimantan & 81.24 \\
\hline & Bali & 79.83 \\
\hline & South Sumatera & 79.81 \\
\hline \multirow{6}{*}{ The Lowest } & Maluku & 65.90 \\
\hline & Riau & 65.83 \\
\hline & West Nusa Tenggara & 65.08 \\
\hline & North Maluku & 61.52 \\
\hline & West Papua & 59.97 \\
\hline & Papua & $\mathbf{5 7 . 5 5}$ \\
\hline
\end{tabular}

Source: Indonesia Democracy Index, 2016

\subsection{Determinants of Regional Income Inequality \\ 1.2.1 Socio-Political Factors \\ 1.2.1.1 Democracy}

The relationship between democracy and income inequality can be analyzed from many persuasive approaches. Sirowy and Inkeles (1990) examine the theoretical relationship between democracy and income equality based on three models: the Democratic Model, The Authoritarian Model and the Skeptical Model (Feng, 2003).

The first model argues that democracy will lead to a reduction in income inequality while the authoritarian regime will increase the inequality (Feng, 2003). In essence, the democratic process will shift the political power from the high-income households to lower income groups, which in turn will result in more equitable income distribution. In contrast, an authoritarian regime will run policies that benefit the rich minority who has the financial power at the cost of the poor majority (Feng, 2003). This model is along with the median voter theory which argues that the political leaders in democratic regimes have an incentive to redistribute wealth in order to appeal to voters (Ha, 2012). With equal distribution of political power in society, it will in turn create political competition, which in turn helps reduce income inequality ( $\mathrm{Ha}, 2 \mathrm{Ol2})$. If there is no competition between political groups (as in authoritarian regimes), the government is more vulnerable to pressure from individuals to benefit the rich at the expense of the poor. In contrast, when there is 
competition between political groups (such as in democratic regimes), the political elites are more likely to respond to the interests of the poor or the middle class (Ha, 2012).

Sirowy and Inkeles also argued that democracy is perceived as a system that tends to avoid economic growth policies that have a negative impact on a particular social group or ignore the interests of the community (Feng, 2003). "Because of electoral mechanisms and rights to opposition and participation, democracies are relatively open to battles over the distribution of societal resources"(Feng, 2003, p.215). In conclusion, based on this approach democracy will reduce the income gap in the society.

Along with this theory, some scholars also argue that the democratic governments tend to help middle-and low-income communities by running a range of policies that emphasize on improving the income redistribution such as cash transfers, progressive tax system, minimum wage policy and price subsidies (Nikoloski). In contrast, authoritarian governments are more accountable to the communities that are relatively wealthier and more powerful. They tend to adopt a more favorable public policy for this group and in turn increase income inequality (Reuveny and Li, 2003).

The second model argues that authoritarian governments are better able to reduce the level of income inequality (Feng, 2003). The assumption of this model is that the income gap is caused mainly by the political gap (in this case is "deficient political representation")(Feng, 2003, p.216). It is often the case in developing countries where democracy is not fully consolidated. This will result the interests and demands from the low and middle-income groups cannot be "heard". Thus, the proponents of this second model states that authoritarian governments are better able to protect the interests and meet the demands of low and middle income groups (Feng, 2003). This is also in line with Hayek's opinion stated that "...a claim for equality of material position can be met only by a government with totalitarian powers" (Feng, 2003, p.216).

Finally, the third model argues that "the relationship between democracy and income equality is spurious" (Feng, 2003, p.216). Hewitt, in his article, stated that this argument falls into two variants (Hewitt, 1977). One argument is the so called-The Functionalists- which argues that: "the form of government, whether democratic or nondemocratic, socialist or non-socialist, does not affect the stratification system since the "needs" of modern industrial economies will require similar differentials in earnings between occupational groups, similar mobility rates and similar government policies, etc" (Hewitt, 1977, p.452). In other words, this argument assumes that there is no connection between income distribution and democracy and linking the income inequality only to the level of industrialization.

Like the Functionalists, though for different reasons, the Marxists assume that: "politics, as practiced in non-communist societies at least, has very little impact" (Hewitt, 1977, p.452). This model assumes that democratic government is not important. The proponents of this particular model focus only on class conflict between capitalists and labor, where the capital holders - the upper income households are relatively stronger than the latter and they are able to dominate or control the state policies (Hewitt, 1977). In turn, they are able to exercise their power to maintain their economic position.

In addition, based on the theory of resources "or" class struggle approach to politics, redistribution of income does not automatically occur after democracy (Ha, 2012). This theory argues that "the distribution of power between labor organizations and the organization of left parties on one side and the center and right-wing political forces on the other side" will determine the size and impact of democracy on a country's income equality ( $\mathrm{Ha}, 2 \mathrm{Ol2}, \mathrm{p.8})$. 
Based on the analysis above, I hypothesize that democracy does not have an impact on income inequality.

\subsubsection{Education}

Education is generally seen as one of the most efficient ways to reduce income inequality (Toh, 1984 as cited in Abdullah, et.al, 2011). Through education, the poor can have a greater economic opportunity (Blanden and Machin, 2004, as cited in Abdullah, et.al, 2011). They were able to determine the choice of employment and salary levels as a signal of ability and productivity in the labor market. In addition, education is able to shift the composition of the labor force is not skilled toward the more skilled. Another reason to support the argument that the positive relationship between education and income gap is that educational achievement plays an important role as a signal of ability and productivity in the job market (Abdullah, et.al, 2011). The selection and assessment process inherent in the education system indicates that individual performance has been determined before workers: „... will be selected into the occupational structure in which their particular educational background will be most productively employed" (Tan, 1982:26 as cited in Abdullah, et.al, 2011). While this process may very well initially increase income inequality (Chiswick, 1968 as cited in Abdullah et.al, 2011), in the long term is expected to reduce income inequality (Schultz, 1963 as cited in Abdullah et.al, 2011).

\subsubsection{Economic determinants}

\subsubsection{Regional GDP per capita}

Much attention has been given to how the distribution of income changes during development. Simon Kuznets (1995) hypothesized the existence of an inverted $U$ curve that initially when the development starts, income distribution will be uneven, but after reaching a certain level of development, the more equitable distribution of income. Kuznets finds the relation between income distribution and the level of per capita income inverted $\mathrm{U}$-shaped. This result is interpreted as the evolution of income distribution in the process of transition from a rural economy to an urban economy. At the beginning of the process of development, inequality in income distribution rose as a result of the process of urbanization and industrialization, at the end of the development process, inequality decreases.

There are many reviews that try to explain why in the early stages of economic growth, income distribution tends to deteriorate and then starts to improve. One of the prominent models is the so- called the Dual Sector Model by Arthur Lewis. This theory states that in the early stages, economic growth will be concentrated in modern industry sectors characterized by relatively high productivity and wages but limited employment opportunities. This will initiate income gap between modern industries and traditional agriculture sectors rapidly before finally after pass the threshold the gap narrow again (Siswanto, 2011).

\subsubsection{Regional Government Spending}

The role of government which is reflected through government spending is an important factor in promoting economic growth. Government spending will affect economic growth through programs or activities which may increase productivity of existing resources, thus reducing the level of inequality of development that occurs within a region.

Education and health are two main programs that are generally perceived have important roles in reducing income inequality. Schultz states that one way to reduce income inequality, the necessary increase in human resources and increased government support for the sector education is one way to achieve this. Some theoretical models also predict that education can reduce income inequality (Schultz, 1963 as cited in Abdullah et.al, 2011). Furthermore, along with the 
development of theories and hypotheses regarding the impact of education on the income inequality, a number of hypotheses linking health and income disparities also continue to expand. Several hypotheses include: First, poor health can make the prospective job seekers is difficult to get a job, or for those who already will be less likely to have jobs that employers will continue to hire them. This is referred to as the effect of the labor market (Labor Market Effect). Second, through the effect of education, poor health levels of the past can affect educational outcomes. In addition, levels of health can also affect a person's performance during the school through attendance at school level or inability to concentrate while at school (Leigh, et al, 2009).

\subsubsection{Foreign Direct Investment}

Investment including foreign direct investment (FDI) is an important factor in promoting economic growth. FDI can take the form of establishment of company's branches or holding companies. In developing countries, FDI inflows are generally preferred compared with inflows of capital in the form of a portfolio with the following reasons. First, FDI can provide advance science and technology for developing countries to assist the development of domestic companies to operate more efficiently. Second, FDI inflows are expected to create jobs and to reduce unemployment rate. Therefore, according to this explanation, FDI inflows are expected to be able to reduce income inequality in developing countries. However, contrary to this theoretical expectation, income inequality in developing countries actually increased after the increase in FDI ( $\mathrm{Ha}, 2 \mathrm{Ol3})$.

FDI is considered to facilitate the deployment of technology from developed countries to the developing ones. Although the developed countries do not always transfer their best technologies to developing countries but this new technology still requires relatively higher skilled labors. It means that sectors actually which are actually grown and developed by FDI tend to be capital-intensive sectors, and capital-intensive industries also tend to be skilled-labor intensive (Feenstra and Hanson 1997 as cited in $\mathrm{Ha}, 2013$ ).

Confirms the above argument, I assume that that multinational companies in developing countries pay higher wages to skilled workers from local companies.

\section{Literature Review}

In this section, I will provide some previous research on the impact of socioeconomic and political factors on income inequality.

Nearly related to the Kuznets theory is the part that economic development plays important role in the distribution of income (Nikoloski). As indicated by the "growth" impact, economic development has a tendency to diminish income imbalances as the wage of the poor increases because of increments in salary (Mckay et al, 2003, as cited in Nikoloski). White and Anderson (2001) also find that the impact of economic development has been the fundamental factor for the poor in order to have a better wage. Barro (2000 as cited in Nikoloski) confirms that development diminishes imbalance. In a comparative design, Ravaillon (2001 as cited in Nikoloski) contends that the efforts of poverty reduction in the less developed countries have been more fruitful especially when those countries reached high development rates joined with falling income inequalities (Nikoloski)

Several studies of the impact of multinational companies in general or FDI to inequality among others Feenstra and Hanson (1997), Figini and Gorg (1999) and Taylor and Driffield (2005) (As cited in Figini and Gorg, 2006). By using industrial data for the state of Mexico, Ireland and the UK, the authors found that there is a relationship between the relative wage and FDI inward FDI which increases the wage inequality. Tsai (1995) studied the relationship between FDI and inequality 
by using a sample of 33 developing countries and found that FDI has increased inequality in some Asian countries. Gopinath and Chen (2003) also found the same thing using a sample in which 11 developing countries, found that FDI flows have widened the wage gap between skilled and unskilled labor (Figini and Gorg, 2006).

The main proponents of the inverse $U$ shape curve theory include Bourguignon and Verdier and Acemoglu and Robinson (Chong, 2001). In the simple version, Bourguignon and Verdier present a model in which public decisions were taken only by the educated group, while the group with no education was not allowed to vote. In the end, this educated group should subsidize people were not educated in order to have access to more knowledge and the result is a reduction in inequality. Acemoglu and Robinson found that the rise of industrialization, in the short term, would encourage the wealthy people to accumulate capital while the poor people could afford to do it. In their models, this would lead to an increase in income inequality. However, after reaching a critical inequality threshold, the intensity of revolution rose and the elites began to spread their political rights and economic resources to the poor. This in turn would result in an increase in redistribution and decrease inequality. (Chong, 2001)

Along with the above argument, Burkhart (1997) argued that the link between democracy and inequality did exist and it was nonlinear. He mentioned that at the earlier stages, democratization efforts would increase inequality. At initial stages, as countries started and became more democratic, the economic benefits tended to accrue the urban middle class first and causing gap. As democracy took hold, the urban working class and rural population catch up in acquiring income and increasing income equality (Burkhart, 1997). Essentially, he argued that democracy was good for income distribution only at later stages.

Having conducted a rigorous analysis, Bollen and Grandjean (1981) did not find any significant evidence to support the view that political democracy contributes to a more egalitarian distribution of income in a sample of 50 countries, once economic development was controlled.

Bollen and Jackman (1985) found that democracy did not affect inequality nor did the opposite. They constructed simultaneous equations model to test the relationship between income inequality and democracy. By using the hypothesis of an inverted $U$ shape, they defined inequality as a curvilinear function of the level of economy. The main result of this study proved that there was no significant effect between democracy and inequality and between inequality and democracy (Ozer, 2008).

Several other studies also examined the effect of timing of a country's democracy and its impact on inequality. Hewitt (1977), examined the impact of democracy in 25 industrialized countries and found no significant relationship, after controlling for other variables (Ozer, 2008).

Muller (1988) tried to replicate the study from Hewitt by increasing the sample size to 50 countries and concluded that at least it took about 20 years for income inequality could be reduced after the introduction of democracy in the country. In other words, democratic institutions, if they were maintained for a relatively long time, could lead to a gradual reduction of income inequality (Ozer, 2008).

Chong (2001) in his simple cross country regression, for the period 1960-1995 argued that there was a non-linear relationship between democracy and inequality. Also, he found that the role of the state was very important to understand the trend of income inequality. Due to the increase in the public sector's size, this elite minority would allocate limited resources for the development of specific sectors/groups or for the protection of the interests of the industry/particular groups, which would affect in the widening of income gap between sectors or social groups. However, he found that after a certain threshold, the increase in the size of government, it would 
likely lead to a reduction in income inequality.

Husni (2011) also found similar result in the case for Indonesia. In his research, he found that the budget allocation for the bureaucracy was one of the causes for income inequality in Indonesia. The budget allocation for the bureaucracy had increased steadily from year to year while allocation for health sector had decreased.

Plenty of empirical evidence, which recommended a solid relationship between education and income inequality, had developed since the original work of Mincer (1958). For instance, an investigation done in Brazil in 1977 uncovered that higher pay earners enjoyed more benefits from good education and training since their childhood (World Bank, 1977, as cited in Nikoloski). Related to government spending, Glomm and Ravikumar developed a model in which people can choose between public and private education systems. Despite the ambiguity found between the private education system and income inequality, but they clearly stated that income inequality would decrease under the public education system (Glomm and Ravikumar, 1992). Saint - Paul and Verdier (1992), Eckstein and Zilcha (1994), Zhang (1996) and Sylwester (2002) also developed a model that supports the hypothesis in which education could lower levels of income inequality over time (Abdullah, et.al, 2011).

However, some of the previous research results showing the opposite direction. For instance, Chiswick (1974) found that higher level of education led to an income inequality. Interestingly, Ahluwalia (1976) discovered a negative relationship between school enrollment and income inequality. Later studies by Sylwester (2003) and Georgio (2003) discovered a negative relationship between higher training and education enrollment and income disparity (Abdullah, et.al, 2011).

\section{Model and Hypothesis}

\subsection{Model}

Based on several studies and theoretical background explained above, I try to introduce my model which is going to be implemented in this study. I incorporate all the aforementioned factors in the following model using Ordinary Least Squares (OLS) regression.

Relations of the above-mentioned variables will be analyzed using software Stata12. Multivariate analysis using Ordinary Least Squares (OLS) will be run to understand the relationship between independent and dependent variables. Given the type of data in this study, we expect that there will be heteroskedasticity problem because this study deals with cross sectional data. When heteroskedasticity issue is present in the data set, the OLS is still unbiased but not efficient. To eliminate this problem, I use robust regression to estimate the coefficient variables.

\subsection{Data}

This article uses Provincial Gini in Indonesia as the dependent variable, while Provincial Democracy Index, Provincial GDP per capita, Provincial Government Spending (Health, Education and Wages), and Religion are the independent variables. All of the data are 2015 data and they are collected based on Statistics of Indonesia's publication.

This paper will use the Indonesia Democracy Index data. This data is based on three critical aspects which are civil liberty, political rights, and institutions of democracy. The Civil Liberties questions are grouped into several sub-categories such as Freedom of Expression, Freedom of Belief, and Associational and Organizational Rights. Political Rights questions are categorized in Electoral Rights and Political Participation. Lastly, Institution of Democracy is divided into Electoral Process, The Role of Parliament, and Independent Judiciary. All these aspects, which are 
including 11 variables and 28 indicators, are used to form Indonesia Democracy Index (Indonesia Democracy Index, 2011).The highest number of index that can be awarded is 100 while the lowest is 0 and this index varies across provinces in Indonesia. This democracy index is divided into three performance categories: good (index > 80), medium (index $60-80$ ), and bad (index <60).

This paper will also try to apply various government spending types such as on education, health, and government spending for salary and wages. The reason is because there are many public expenditure programs that might have a propoor nature and thus help to reduce income inequality even without direct income transfers. These types of expenditures might explicitly be targeted to the poor per se can also contribute to improve the distribution of income in the short and longer term

FDI is another variable of interest, standing for log for foreign direct investment in province. The data for this variable are taken from BPS. Also, this paper uses religion as one of the variables because religion is often ignored. In fact, religion plays both negative and positive roles in relation to inclusive growth. On the one hand, religion-related hostilities, prejudices and biases can lock people out and inhibit inclusive growth. On the other, religious organizations have a tremendous capacity for doing good, with most religious groups being known for their programs to address poverty and/or care for the poor.

\subsection{Hypothesis}

Based on the theory and previous studies, I establish hypotheses as follows:

1) In terms of RGDP per capita

$\mathrm{HO}=\mathrm{O}$ : There is no relationship between GDP per capita and Gini Index.

Halt < 0 : There is a negative relationship between GDP per capita and Gini Index It means that if the GDP per capita increases, then we expect the Gini Index to decrease.

2) In terms of Ratio of Government Spending on Education to the Total

Government Spending

$\mathrm{HO}=\mathrm{O}$ : There is no relationship between Ratio of Government Spending on

Education to the Total Government Spending

Halt: < 0 : There is a negative relationship between Ratio of Government Spending on Education to the Total Government Spending. It means that if the ratio of Government Spending on Education to the Total Government Spending increases, we expect that Gini Index to decrease

3) In terms of Ratio of Government Spending on Health to the Total Government Spending

$\mathrm{HO}=\mathrm{O}$ : There is no relationship between Ratio of Government Spending on

Health to the Total Government Spending

Halt: $<0$ : There is a negative relationship between Ratio of Government

Spending on Education to the Total Government Spending. It means that if the ratio of Government Spending on Health to the Total Government Spending increases, we expect that Gini Index to decrease

4) In terms of FDI

$\mathrm{HO}=\mathrm{O}$ : There is no relationship between FDI and Gini Index.

Halt: > O: There is a positive relationship between FDI and Gini Index. It means that if FDI increases, we expect that Gini Index to increases 


\section{5) In terms of Democracy}

$\mathrm{HO}=\mathrm{O}:$ There is no relationship between Democracy and Gini Index.

Halt > O: There is a positive relationship between Democracy and Gini Index. It means that if the Democracy increases, then we expect the Gini Index to increase.

\section{Results and Conclusion}

I start my analysis using 4 models. The first model is the basis that only includes democracy in the regression. Model 2 adds economic variables, while still keeping democracy as a control variable. Model 3 uses only social variables and democracy. I finally end my estimation with a comprehensive model 4, which also includes regional dummy variable (1=eastern part of Indonesia, $\mathrm{O}=$ western part of Indonesia). Table 2 below will show the results of the multivariate statistical analysis in this study.

There are a few important results that emerge from this analysis. First, I find weak impact of democracy on income inequality in this model (as expressed by high $\mathrm{p}$ value at all models). In all of my models, democracy appears as insignificant. Even in the basic model, democracy is insignificant at one tail 10 percent level of significance. This result implies that even the simplest model between democracy and income inequality it does not yield a robust result that could be used to prove whether democracy has any impact on income inequality. I argue that, seemingly, redistribution of income does not automatically occur after democracy is introduced. Similar results are also found by Bollen and Grandjean (1981) and Bollen and Jackman (1985).

Second, I find strong evidence that government expenditure especially for education and health influence inequality. In the second and fourth model, it is shown that the estimated coefficients are consistent and significant at one tail under 5 percent errors. This result is consistent with other similar studies such as by Glomm and Ravikumar where they developed a model in which people can choose between public and private education systems and found that income inequality will decrease under the public education system (Glomm and Ravikumar, 1992). Saint - Paul and Verdier (1992), Eckstein and Zilcha (1994), Zhang (1996) and Sylwester (2002) also developed a model that supports the hypothesis in which education can lower levels of income inequality over time.

Table 3. Regression Results on Gini Index

\begin{tabular}{|c|c|c|c|c|}
\hline Variable & Model_1 & Model_2 & Model_3 & Model_4 \\
\hline Democracy & $\begin{array}{l}0.00105 \\
(0.3252)\end{array}$ & $\begin{array}{l}0.00133 \\
(0.3505)\end{array}$ & $\begin{array}{l}0.00003 \\
(0.9807)\end{array}$ & $\begin{array}{l}0.00207 \\
(0.2897)\end{array}$ \\
\hline Regional GDP per Capita & & $\begin{array}{l}-0.0000 \\
(0.8355)\end{array}$ & - & $\begin{array}{l}0.0000 \\
(0.6717)\end{array}$ \\
\hline FDI & & $\begin{array}{c}0.00001 \\
(0.0584)^{*-4}\end{array}$ & $\cdot$ & $\begin{array}{c}0.00001 \\
(0.0557)^{* *}\end{array}$ \\
\hline Health Spending/Total Spending & & $\begin{array}{l}-0.00321 \\
(0.1053)^{* *}\end{array}$ & - & $\begin{array}{r}-0.00403 \\
(0.1384)^{*}\end{array}$ \\
\hline Education Spending/Total Spending & & $\begin{array}{c}-0.00430 \\
(0.0006)^{\text {kt**}}\end{array}$ & - & $\begin{array}{l}-0.00332 \\
(0.0491)^{* *}\end{array}$ \\
\hline Wage+Allowance/Total Spending & & $\begin{array}{c}0.00124 \\
(0.2092)^{*}\end{array}$ & - & $\begin{array}{l}0.00048 \\
(0.6890)\end{array}$ \\
\hline Mean Years of Schooling & & - & $\begin{array}{c}-0.00301 \\
(0.7185)\end{array}$ & $\begin{array}{l}-0.01197 \\
(0.2753)\end{array}$ \\
\hline Moslem & & $\cdot$ & $\begin{array}{c}-0.00027 \\
(0.5440)\end{array}$ & $\begin{array}{c}-0.00013 \\
(0.7924)\end{array}$ \\
\hline
\end{tabular}




\begin{tabular}{|c|c|c|c|c|}
\hline Christian & & - & $\begin{array}{c}-0.00076 \\
(0.3969)\end{array}$ & $\begin{array}{l}-0.00071 \\
(0.4886)\end{array}$ \\
\hline Hindu & & - & $\begin{array}{c}-0.00004 \\
(0.9212)\end{array}$ & $\begin{array}{c}-0.00040 \\
(0.4415)\end{array}$ \\
\hline Buddha & & - & $\begin{array}{l}-0.00428 \\
(0.3553)\end{array}$ & $\begin{array}{l}-0.00437 \\
(0.2159)\end{array}$ \\
\hline Region & & - & $\begin{array}{c}0.03720 \\
(0.0488)^{* *}\end{array}$ & $\begin{array}{l}0.03009 \\
(0.1678)^{*}\end{array}$ \\
\hline Cons & $\begin{array}{c}0.42972 \\
(0.0000)\end{array}$ & $\begin{array}{l}0.29740 \\
(0.0027)\end{array}$ & $\begin{array}{l}0.40372 \\
(0.0008)\end{array}$ & $\begin{array}{l}0.37316 \\
(0.0263)\end{array}$ \\
\hline $\mathrm{N}$ & 33 & 33 & 33 & 33 \\
\hline R2 & 0.026 & 0.312 & 0.295 & 0.497 \\
\hline Adj R2 & -0.005 & 0.154 & 0.099 & 0.195 \\
\hline
\end{tabular}

Source: Stata 12

$p$ value are in the parentheses

${ }^{*} p<0.1,{ }^{* *} p<0.05,{ }^{* * *} p<0.01$ one tail

Along with these results, even though it is insignificant I find that government expenditure on salary and allowance for government officials has a positive. It means that an increase in the government expenditure for government officials will increase inequality. This result is along with the state-centered theory argued by Lee (2005). In his article, Lee argues that one of the main impacts of government size on overall income inequality is through "encouragement of uneven resource allocations and income differentials among employees between public and private sectors" (Lee, 2005, p.160)

Third, in my models, I find evidence with 5 percent level of significance that foreign direct investment increases inequality. As discussed in the literature review, I hypothesized that countries that are more open and more involved in the foreign investment tend to exhibit higher levels of inequality.

Finally, acknowledging that regional factors also play an important role in the economy and income distribution, I find insignificant results of this variable distribution of income. Even though the result is not significant, I find that provinces in the eastern part of Indonesia have higher Gini index compared to western part and this is consistent with the Kuznet's finding. Kuznets (1963) argues that in the early stages of development, income inequality will increase. In this case I argue that eastern part of Indonesia is in the early stage of economic development. My argument is supported by the data that the average economic growth for all provinces located in the eastern in 2015 reached 7.1 percent, higher than the average from all provinces in the western part, which reached 5.5 percent (National Development Planning Agency, database). Nonetheless, the share of economic growth is showing the opposite picture as expressed in figure 3 below. 


\section{Share of Economic Growth}

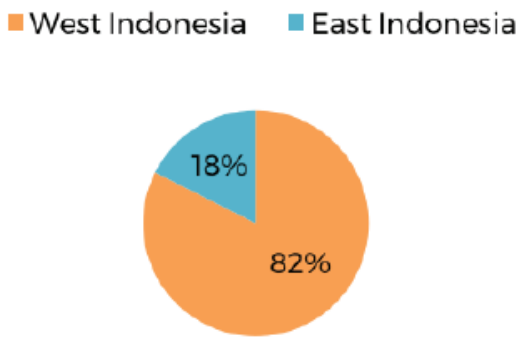

Source: National Development Planning Agency, database

In this paper I try to analyze and examine the relationship between economic, social and political factors on income inequality in Indonesia. By using OLS method, the study did not find strong evidence that democracy has an influence on inequality. In addition, the study found a significant relationship between government spending and income inequality. In addition, I also found evidence that foreign direct investment flows generate income inequality in Indonesia. There are several relevant policy conclusions that can be drawn from this study.

First, economic factors have a more significant impact on the income gap compared to the social and political factors. Therefore, in order to overcome the problem of income inequality, the policy emphasis should be placed on measures that affect economic policies such as regulations on the inflow of foreign capital. Secondly, the government needs to increase spending on those sectors, which have the effect of reducing the gap such as education and health keeping in view the fiscal capability.

Further study of some of the determinants of inequality is obviously needed. There are a few could be better why the results may not be convincing. This could be due to the limitation of the model. This study only picks one year as a focus of study. In the future, time series models could be more beneficial in understanding the impacts of economic and socio-political factors on income inequality. 


\section{References}

ADB. (2015). Indonesia: Interim Country Partnership Strategy (2015). Retrieved from http://www.adb.org/documents/indonesia-interim-country partnership-strategy-2015

Abdullah, et.al. (2011). Does Education Reduce Income Inequality? A Meta-Regression Analysis. Journal of Economic Survey. 2013.

Anshori,et.al.(2013).TheLong-runEvolutionofInequalityInIndonesia, 1990-2012: New Estimates and Four Hypotheses On Drivers. Center for Economics and Development Studies, Department of Economics, Padjadjaran University. September 2013.

Boix, C. (1998). Political parties, growth and equality: Conservative and social democratic economic strategies in the world economy. Cambridge University Press. Cambridge, UK.

Bollen, K.A. and R. Jackman. (1985). Political Democracy and the Size Distribution of Income. American Sociological Review 50:438-57.

Bollen, K.A. and B. Grandjean. (1981). The Dimension(s) of Democracy: Further Issues in the Measurement and Effects of Political Democracy. American Sociological Review 46:232-39.

Burkhart, R. (1997). Comparative Democracy and Income Distribution: Shape and Direction of the Causal Arrow. The Journal of Politics. Cambridge University Press. Cambridge, UK.

Chong, A. (2001). Inequality, Democracy, and Persistence: Is There a Political Kuznets Curve. Inter-American Development Bank and Georgetown University.

Feng, Y. (2003). Democracy, Governance, and Economic Performance. Theory and Evidence. The MIT Press. Cambridge, Massachusetts.

Figini, P., Holder Gorg (2006). Does Foreign Direct Investment Affect Wage Inequality? An Empirical Investigation. Discussion Paper No 2336. September 2006. The online version of this article can be found at: http://ftp.iza.org/dp2336.pdf

$\mathrm{Ha}$, E. (2012). Globalization, Government Ideology, and Income Inequality in Developing Countries. Journal of Politics. 74(2), April 2012

Hewitt, C. (1977). The Effect of Political Democracy and Social Democracyon Equality in Industrial Societies: A Cross-National Comparison. American Sociological Review, Vol. 42, No. 3. American Sociological Association.

Huber, E.and J.D. Stephens. (2001). Development and Crisis of the Welfare State: Parties and Policies in Global Market. Chicago, IL: University of Chicago Press.

Husni (2011). Sekelumit tentang politik anggaran di Indonesia. (http://www.academia.edu/2547121/Sekelumit_Politik_Anggaran Indonesia)

Lee, C S. (2005). Income Inequality, Democracy and Public Sector Size. American Sociological Review, 2005, 70:158. Sage Publication. The online version of this article can be found at: http://asr.sagepub.com/content/70/1/158

Leigh, et.al (2009). Health and Economic Inequality. The Oxford Handbook of Economic Inequality (2009). The online version of this article can be found at: http://andrewleigh.org/pdf/HealthInequalityOUP.pdf

Milanovic, Branko. (2000). The Median-Voter Hypothesis, Income Inequality and Income Redistribution. European Journal of Political Economy Vol. $16 \mathrm{p}$. 367-410.

Nel, Phillip. (2005). Democratization and the Dynamics of Income Distribution in Low and Middle-Income Countries. Politikon Vol. 32 (1) p. 17-43.

Nikoloski, Z. Economic and Political Determinants of Income Inequality. University College London, London, United Kingdom. 
Ozer, B. (2008). The Impacts of Democracy on Income Inequality. Seminar Papers in Development Economics School of Business and Economics - Institute of Public Economics. Humboldt-Universitat Zu Berlin.

Reuveny, R., Quan Li. (2003). Economic Openness, Democracy and Income Inequality. Comparative Political Studies.

Siswanto, P. (2011). Analisa Dampak Perdagangan Bebas Terhadap Ketimpangan Wilayah. Skripsi. Fakultas Ekonomi Universitas Diponegoro, Semarang. 2011 